\title{
Whether to Ignore Them and Spin: Moral Obligations to Resist Sexual Harassment
}

\author{
CAROL HAY
}

In this essay, I consider the question of whether women have an obligation to confront men who sexually harass them. A reluctance to be guilty of blaming the victims of harassment, coupled with other normative considerations that tell in favor of the unfairness of this sort of obligation, might make us think that women never have an obligation to confront their harassers. But I argue that women do have this obligation, and it is not overridden by many of the considerations that can override other obligations to confront wrongdoers.

Sexual harassment is a problem that has received a great deal of attention from both feminist activists and feminist scholars, who have explained at great length why it is morally problematic, how it harms women, and what should be done to eradicate it. But what has not received much attention is the issue of what moral expectations, if any, we should have of women who find themselves subjected to sexual harassment. This is hardly surprising: as I discuss below, a number of different considerations might make us think that women never have an obligation to confront those who sexually harass them. Perhaps the most important among these considerations is feminists' perfectly appropriate reticence to be guilty of victim-blaming. A woman who has been sexually harassed has been subjected to a moral harm, and it seems strange to suggest that being subjected to a moral harm might actually impose moral obligations on the victim, instead of the perpetrator. Strange as it might initially seem, I want to consider just this possibility. In the end, I make a case for the claim that a woman who has been sexually harassed has a moral obligation to confront her harasser. It will 
turn out that this obligation arises as a special case of a woman's obligation to preserve and protect her own autonomy or moral agency.

A concrete example might lend plausibility to this admittedly rather unintuitive claim. In his essay for Harper's magazine, "Getting Away from Already Being Pretty Much Away from It All," David Foster Wallace describes his visit to the Illinois State Fair. The friend who goes with him, whom he calls Native Companion because she's a local, gets on one of the fair's rides. While she is hanging upside down, the men operating the ride stop it so that her dress falls over her head and they can ogle her. What follows is the exchange that takes place between Wallace and Native Companion immediately after she gets off the ride. Wallace speaks first.

Did you sense something kind of sexual-harassmentish going on through that whole little sick exercise?"

"Oh for fuck's sake ... it was fun." . . .

"They were looking up your dress. You couldn't see them, maybe. They hung you upside down at a great height and made your dress fall up and ogled you. They shaded their eyes and made comments to each other. I saw the whole thing."

"Oh for fuck's sake." . . .

"So this doesn't bother you? . . . Or did you just not have an accurate sense of what was going on back there?"

"So if I noticed or I didn't, why does it have to be my deal? What, because there's assholes in the world I don't get to ride on The Zipper? I don't get to ever spin? Maybe I shouldn't ever go to the pool or ever get all girled up, just out of fear of assholes?"

"So I'm curious, then, about what it would have taken back there, say, to have gotten you to lodge some sort of complaint with the Fair's management."

"You're so fucking innocent," she says. "Assholes are just assholes. What's getting hot and bothered going to do about it except keep me from getting to have fun?" (Wallace 1997, 100)

When Wallace suggests to Native Companion that other women might "Confront the ogler, [or] file an injunction," she replies, "They might ought to try just climbing on and spinning and ignoring assholes and saying Fuck 'em. That's pretty much all you can do with assholes" (101).

Right, then. I think this exchange raises some very interesting questions: Is a decision to ignore behavior that stems from oppressive norms a legitimate way to react to oppressive social conditions? What sorts of obligations do women have to resist patriarchal oppression, and do these obligations differ from the obligations men have? What sorts of obligations do women have to stand up to 
perpetrators of sexual harassment? If, as Native Companion suggests, all you can do with harassers is ignore them, what are the prospects for real social change? What follows is an attempt to answer these questions. In the end, I will argue that women often do have a moral obligation to confront the men who harass them. Furthermore, I will argue that this obligation is not overridden by many of the sorts of considerations that can override other moral obligations.

But first, some preliminary issues must be dealt with. We must be clear on exactly what sort of harm someone like Native Companion has undergone. I will argue that because she's been subject to sexual harassment, her autonomy has been undermined. But in order to see this as a bad thing, we need to understand why autonomy is a concept that feminists need to take seriously. Only then can we move on to consider what sorts of obligations a woman like Native Companion might have to confront her harassers.

\section{The Harm of Sexual Harassment}

Exactly what sort of harm is sexual harassment? I want to argue that sexual harassment stems from sexual objectification. Following Linda LeMoncheck, I take it that women are sexually objectified whenever they are "regarded as inanimate objects, bodies, or animals, where their status as the moral equals of persons has been demeaned or degraded," or when they are treated as if they are "being[s] with more restricted rights, less of the rights, or none of the rights to well-being and freedom that other persons (in particular, [their] objectifiers) enjoy" (LeMoncheck 1994, 202, 205). LeMoncheck stresses the importance of distinguishing between treating a woman as a sex object, which is morally problematic, and treating her as sexually attractive or as the object of sexual desire, which need not be morally problematic. There are many contexts in which it is perfectly appropriate to treat a woman as sexually attractive or as the object of sexual desire. What is common to all these contexts is that the woman's sexuality is actually relevant to the situation and that she is treated as a moral equal. Sexual objectification occurs only when a woman is treated as sexually attractive in a context where her sexuality is, or ought to be, irrelevant, or when she is not treated as a moral equal because of her sex.

One can sexually objectify a woman simply by thinking about her in a certain way; the woman need not be aware that she has been objectified for it to be true that she has been objectified. I take sexual harassment, on the other hand, to be the outward behavior that arises from sexual objectification. But just because a woman must be aware of the offending behavior in order to be sexually harassed, she need not take herself to have been harassed in order for her to have actually been harassed. If the behavior occurs because a woman has been sexually objectified, the behavior is sexual harassment, regardless of how it is perceived. 
Further, following Anita Superson, I want to argue that the harm a woman experiences when she is sexually harassed is not aimed at her as an individual; the harasser is able to harass her because she is a member of an oppressed group to whose members he does not accord the proper amount of moral respect (Superson 1993a, 51; 1993b, 41). So the harm of sexual harassment differs from other kinds of harms, because it both draws on and reinforces certain oppressive social norms. This means that when a particular woman is sexually harassed, all women are in fact harmed.

Native Companion's treatment at the hands of the carnival workers is a clear case of sexual harassment: they treat her as worthy of so little respect that they act as if they are perfectly justified in "ogling her nethers" (Wallace 1997, 101). One does not ogle the nethers of a moral equal without her permission. And riding The Zipper hardly constitutes permission to be ogled. These men have treated Native Companion as a sexual object in a situation where her sexuality ought to be irrelevant. So whether she feels affronted or not, Native Companion has been sexually harassed.

The harm of sexual harassment should not be underestimated. When a woman is sexually harassed, or sexually objectified more generally, she has not been treated as a moral equal. This means that she has not been accorded the respect of an autonomous agent. But sexual harassment is not merely evidence of a lack of respect for women's autonomy; it also undermines their autonomy. It makes them less autonomous. How? Sexual harassment does not just occur within the context of women's oppression under patriarchy. It also simultaneously entrenches this oppression by participating in, and thereby reinforcing and legitimating, certain sexist attitudes about women's inferiority to men and about the sex roles that it is appropriate for women to occupy. That is, sexual harassment is not just a manifestation of the sexist attitudes of patriarchal society; it also contributes to, entrenches, and legitimates these attitudes. These attitudes, in turn, reinforce patriarchal oppression. Because oppression limits the autonomy of those who are oppressed, insofar as these sexist attitudes contribute to patriarchal oppression, they constrain, limit, and undermine women's autonomy. ${ }^{1}$ Thus the moral harm of sexual harassment goes beyond any individual instance of a woman not having her autonomy respected. Rather, the moral harm of sexual harassment is that it actually makes women less autonomous.

\section{A Feminist Analysis of Autonomy}

One might wonder why feminists should take the goal of protecting and fostering women's autonomy seriously. Some feminists, most famously Carol Gilligan (1982) and Nel Noddings (1984), have derided the concept of autonomy as nothing more than a masculine obsession that's been dressed up with moral 
and political legitimacy. They argue that detachedness is a characteristically masculine trait and interpret autonomy as nothing more than a valorization of this masculine behavior. They contrast this detachedness with the interconnectedness that is supposedly observed in women and argue in favor of some other, more "feminine" moral ideal. Other feminists, such as Naomi Scheman (1983) and Susan Sherwin (1998), have advocated a shift away from the individualism they see underlying traditional conceptions of autonomy, toward a more relational conception that recognizes that the interests of the individual are inseparable from the interests of others. ${ }^{2}$

But we need not view autonomy in such negative terms, particularly not if we're careful to distill what is central to the concept from so much of the unnecessary and undesirable baggage with which it is often saddled. There are clear tendencies in the canonical liberal writings on autonomy and personal freedom-for example, in the works of Mill, who was explicitly feminist, and in the works of Kant, who should have been feminist if he'd properly understood his own theory-to treat the concepts of autonomy and personal liberty as self-government, and nothing more. This pared-down conception of autonomy as self-government contrasts sharply with the more robust conceptions of autonomy advanced by other thinkers such as Hobbes. The Hobbesean ideal of non-tuism far too easily turns into ideals of selfishness and metaphysical atomism of the self that many feminists rightly criticize as both unrealistic and undesirable. I think it's hard to see autonomy's core ideal of self-government as anything other than a laudable moral aim for women, particularly given that one of the greatest harms of sexist oppression is its restriction of the quality and quantity of choices that are open to women. We can recognize many of the points made by those who are critical of the liberal tradition - that people's decisions are influenced by values that are largely determined by interpersonal relations; that these interpersonal relations are not just inevitable, but also valuable; that the interests of the individual are not cleanly separable from the interests of others-without giving up on the liberal idea that it's important that, ultimately, people be free to make their own choices and promote their self-interest.

Grant, then, that as feminists we should take autonomy seriously. ${ }^{3}$ Now, given that I have at least made plausible the claim that sexual harassment undermines women's autonomy by reinforcing the sexist attitudes that contribute to their oppression, if we want to determine whether a woman like Native Companion might have an obligation to confront her harassers, we need to be clear on exactly what the relationship is between autonomy and moral obligation. 


\section{Autonomy and Obligation}

In general, we hold people morally responsible only for actions that are undertaken autonomously. If one has no autonomy, one has no moral obligation; if one is fully autonomous, one is fully subject to all possible moral obligations that might exist in a situation. And if we think that someone is partially autonomous, we might think that she is partially subject to some or all of the potential moral obligations that exist for someone in a situation like hers. ${ }^{4}$ Perhaps the appropriate amount of moral obligation to demand of someone is always directly proportional to the degree of autonomy she has.

More needs to be said about what the exact nature of the relationship between autonomy and moral responsibility amounts to. We might think the two concepts are interdefined, where moral responsibility just is what is demanded of autonomous moral agents, and autonomous moral agents just are those agents who have certain moral responsibilities. If this is the relationship between the two concepts, it is easy to see why nonautonomous agents are not subject to moral responsibilities, and why fully autonomous agents are fully subject to moral responsibilities. We can even explain those cases of partial autonomy where the amount of moral responsibility is directly proportional to the degree of autonomy.

But there's good reason to suspect that the relationship between autonomy and moral obligation is not as straightforward as this. I suggest that the reason we think that moral obligations don't apply to those who lack autonomy is that it would seem profoundly unfair to require moral obligations of someone who was incapable of actually fulfilling them. And the reason we think obligations do apply to those who are autonomous is that it seems fair to require morally responsible behavior from someone who is capable of living up to what morality requires of them. This is all to say that the judgment of how much moral responsibility it is reasonable to require of an agent is, in the end, a normative judgment. Thinking about obligations in this way can account for those cases in which the appropriate amount of moral responsibility is directly proportional to the degree of autonomy one has. It also leaves room for cases in which the appropriate amount of moral obligation to demand does not appear to be in direct proportion to the amount of autonomy an agent actually has.

We might have political or moral reasons to vary the amount of moral responsibility required of an agent. On the one hand, demanding more responsibility of someone than is called for by a strict principle of direct proportionality might give an agent an incentive to act in ways that would end up increasing her autonomy. Holding someone responsible for something can influence what she actually does, when she knows that she is being held responsible. ${ }^{5}$ On the other hand, we might think it unfair to impose directly proportionate responsibility in a situation where pernicious social factors so restrict an agent's autonomy that the last thing she needs is to be answerable to further demands. ${ }^{6}$ 


\section{Women's Capacity for Autonomous Action}

Clearly, then, women can have an obligation to confront their harassers only if they are actually autonomous. If sexist oppression completely prevents the possibility of autonomous action for women, then the question of what moral obligations women have will obviously not arise. It's clear that patriarchy restricts women's range of options and limits women's choices in ways they wouldn't be in the absence of this oppression. Many of the ostensibly free choices that women make take place under circumstances where the range of meaningful options is so limited that one begins to wonder whether such choices are meaningfully autonomous at all. Furthermore, women actually internalize their oppression: because patriarchal social factors function illicitly to influence women's actual preferences, women end up with preferences that are inimical to their own interests. Because women's preferences end up distorted under patriarchy, even those choices that appear to be unproblematic cases of simple preference-satisfaction are suspect. For if oppressive forces have perverted the content of a preference, it's hard to see how that preference can really be called an autonomous one.

But to claim that women are incapable of any meaningful degree of autonomy under patriarchy would be to go too far. As soon as we think of autonomy as a concept that admits of degrees, we have the conceptual resources to argue that while women would clearly be more autonomous without patriarchy, they are (almost always) not entirely without a significant degree of autonomy even under patriarchy. Despite their oppression, women usually still have a morally significant amount of control over their lives.

I am, however, less comfortable making this sort of claim about the many women today (and virtually all women historically) whose range of options are (and were) so circumscribed that it does not seem unreasonable to say that they are (and were) not autonomous in any real sense at all. I don't want to claim that it's not possible for someone's choices to be so restricted that her autonomy is completely compromised. And I don't think that we have to resort to the your-wallet-or-your-life examples that are common in philosophy to show that this is the case. For many women in the Third World, economic conditions can combine with other social inequalities to preclude completely the possibility of autonomous action. ${ }^{8}$ However, most women in most First World nations can usually be said to have enough autonomy to be considered substantially autonomous. As such, they can be legitimately required to live up to a certain level of moral responsibility. Arguing that patriarchy strips women of all their autonomy would undermine or ignore the real power most Western women actually have. 


\section{Obligations to Confront Wrongdoers}

Still, oppression obviously undermines women's autonomy in a very real way. There's good reason to think this should affect decisions about which moral obligations it is fair to say women have. The question of whether women like Native Companion are responsible for confronting their harassers must be considered within an overall picture that recognizes that women are already subject to conditions of oppression when they are harassed. A situation like Native Companion's might be dissimilar, in morally relevant ways, from other situations where we think people have an obligation to confront people engaging in immoral activities. Because cases of sexual harassment occur in the wider context of oppression, we might think they're unlike seemingly simpler situations where someone does have an obligation to confront a moral offender. Let's consider those simpler cases first.

I think that it's uncontroversial to claim that there are situations where people have a clear moral obligation to confront wrongdoers. A familiar example is this: if you see a group of children setting a cat on fire, and you have it in your power to stop them, and you have no reason to think that intervening would put you at any risk of harm, then you have a clear moral obligation to confront the children in order to rescue the cat. Failing to confront an offender in a case like this seems cold, callous, and possibly even akin to approval of, or collusion with, the immoral act. ${ }^{9}$

Matters are less clear when there is good reason to suspect that confronting a moral offender will put you in danger. A slightly different example is this: you see some children setting a cat on fire, and you have it in your power to stop them, but you know that they are armed and capable of violent rages, and so have good reason to think intervening would put you in harm's way. In such a case, your obligation to confront the children is less clear. The obligation might still exist, but it would be tempered, and possibly even overridden, by considerations of safety. Confronting an offender in a case like this seems supererogatory-not something that reasonably could be morally required of someone. Failing to confront an offender here is understandable and morally justifiable; confronting an offender here seems noble, brave, or possibly even foolhardy.

So when dealing out moral responsibilities, we must keep in mind the caveat that any obligation to confront a moral offender needs to take into account whether doing so will put an agent in danger. Again, this is a normative decision: it seems unfair to require someone to put herself in extreme danger in order to satisfy many, if not most, moral obligations. This is not to say that one can never be morally required to do something dangerous; it is only to say that considerations of risk must be part of the equation when determining how much moral responsibility it is fair to say someone has. 
Still, I take it that the existence of a prima facie moral obligation to confront wrongdoers is uncontroversial enough to require no further defense here. That this prima facie obligation exists means that women have a prima facie obligation to confront the men who sexually harass them. But we've just seen how obligations to confront wrongdoers can be overridden by normative considerations. There's good reason to think that the fact that sexual harassment takes place under patriarchal oppression will give rise to normative considerations that might override women's obligation to confront harassers.

\section{Obligations under Oppression}

The thought that we need to take women's oppression into account when deciding which moral obligations they have is not a new one. For example, Anita Superson has argued that it is morally inappropriate for feminists to require women who conform to traditional gender roles to change their behavior. She thinks this is the case even though she admits that this behavior contributes not only to the oppression of those who conform, but also to the oppression of all women. She argues that it is unfair to say that these women have obligations to resist oppression, because "their choice of lifestyle, and the values and beliefs accompanying it, ... takes place in the context of severe restrictions of their freedom caused mainly by patriarchy. Their lifestyle, in turn, significantly limits their choices further" (Superson 1993b, 40). To say that they have an obligation to change is to "expect them to act in ways that restrict their choices even further," and would be tantamount to blaming the victim. Superson's argument lines up nicely with my claim that the decision about what obligations an agent has is a normative one. And whether or not we agree with her conclusion that oppressed women do not have obligations to resist their oppression-as will become apparent, I don't—an analysis like hers gives us good reason to take seriously the ways in which the fact that someone is oppressed can influence what degree of obligation she has.

There are several reasons why the fact that sexual harassment takes place under the oppressive conditions of patriarchy is relevant to the decision of whether women have an obligation to confront their harassers. First, there are some purely practical considerations. Given how prevalent situations of sexual harassment are in a patriarchal society, confronting every single perpetrator is probably not logistically possible. Furthermore, confronting every harasser could be potentially exhausting and could lead to a sense of victimization that could leave women unable to appreciate their own potential for responsible opposition.

But, more importantly, there are a number of other normative considerations that are relevant here, all of which emphasize how unfair it is to hold women responsible for resisting sexual harassment. We need to recognize that 
a woman who has been harassed suffers real harm-psychological, social, and emotional-and by saying that she has an obligation to confront her harasser, we impose a further burden on her. Because she hasn't done anything wrong, it seems unfair to demand that she take on the burden of trying to rectify the situation. We might think that oppressive social factors have left her with enough on her plate and that the last thing she needs is to be answerable to further moral demands.

There also seems to be something deeply unfair about saying that being harassed gives women a special obligation to fight oppression that is somehow different from the general obligations that everyone has to fight oppression. Sexist oppression is clearly unjust; why isn't everyone equally obligated to fight it? Why isn't society in general seen as remiss, if it doesn't reform itself so that it neither allows nor tolerates sexual harassment? Also, if the obligation that women have to fight their own oppression is somehow different from the obligations that everyone else has, then there's a concern that women who neglect this obligation will be seen as morally derelict, in a way that others aren't.

Further, remember that even men who don't actively contribute to patriarchy still benefit from it. Social institutions, such as the family, the academy, and the workplace in general, favor sexist and nonsexist men alike. Feminist men can refuse to benefit from some of the advantages patriarchy offers them, such as their assumed exemptions from the lion's share of household duties and childcare responsibilities. But other advantages, such as men's increased earning power, social mobility, and relative sense of security that comes from not having to fear being raped, cannot easily be given up, if they can be given up at all. Because men benefit from patriarchy, they are almost certainly better situated to fight it than women; why not think this gives men a special obligation to fight women's oppression?

Finally, there is concern that obliging women to resist sexual harassment risks shifting the moral burden away from harassers and onto their victims. The men who sexually harass women don't just fail to fight patriarchy; they actively perpetuate it. If saying that women have an obligation to confront men who sexually harass them even appears to diminish the moral culpability of men who are guilty of contributing to patriarchy, this is a serious reason to think that we shouldn't be doing this. There is a real concern that thinking about women's obligations to resist their oppression in the way I am advocating unfairly shifts the burden of rectifying the wrongs of patriarchy onto those who suffer under it, instead of onto those who benefit from it - there is concern that my analysis might be blaming the victims.

I certainly am not saying that men are excused from their obligations to fight sexist oppression. Make no mistake: men who do not resist patriarchy are neglecting a moral obligation to fight injustice. This obligation is made all the more pressing by the realization that the power men have under patriarchal oppression 
puts them in a better position to be able to dismantle patriarchy. Similarly, society in general has an obligation to divest itself of unjust institutions. Women are certainly not the only ones who have an obligation to oppose patriarchy.

But I'm also no apologist for patriarchy: I don't want to excuse or justify the ways in which it harms women. If it turns out that one of the ways that patriarchy harms women is that it burdens them with unfair obligations, then this is just one more reason to eliminate it. I think there is good reason to believe that women's obligations to resist their oppression-and thus to confront their harassers-are unfair. But unfair obligations are obligations nonetheless.

Of course, considerations of safety will also often come into play when determining whether to require a woman to confront her harasser. In many cases of harassment, a woman should have every reason to think that confronting her harasser will put her in danger. One of the many harms caused by sexual harassment is that women can end up feeling afraid — afraid of their harasser, but also afraid of their vulnerability in a society that permits such behavior. This fear is not entirely unjustified. As noted above, one of the things that makes sexual harassment particularly problematic is that it treats women as morally inferior to their harassers. If a woman knows that her harasser does not consider her to be a moral equal, she has every reason to be concerned that he will not accord her the sort of respect that would prevent him from harming her in other ways as well. Because the conditions of women's oppression add an element of danger that is not present in nonoppressive situations, our concern for women's safety might completely override any moral obligations we would otherwise require of them. If we have good reason to think women would be at risk of further harm if they have an obligation to confront their harassers, then we cannot morally require this of them. But if we have some assurance that a woman would not face too much further risk by confronting her harasser, we should think seriously about saying that she has an obligation to do so. We cannot afford to be too vague about what we're going to count as potential danger: if we err on the side of caution in every case and never require women to confront their harassers, then the prospects for social change will be very dim. Patriarchy is not likely ever to be eradicated if it is never resisted.

Of course, it might be objected that confronting harassers just isn't worth it because it won't do any good. This seems to be the thrust of Native Companion's claim that the only thing you can do with harassers is ignore them. It's true that for any individual case of confrontation, the effect on overarching social oppressions will probably be negligible. But on a larger scale, such pessimism is unwarranted. For if all, or even most, cases of harassment were confronted, harassers would soon get the message that such behavior was inappropriate. To those who would object that harassers already know that this behavior is inappropriate, but simply don't care, it can be responded that perpetual confrontation might give them reason to care. If harassers found that when they harassed 
women they were subject to acerbic retorts, belittlement, embarrassment, or other undesired consequences, such as negative implications for their career, they would quickly begin to think twice about whether their behavior was worth it. ${ }^{10}$ I suspect that when most men harass women, they do so because they think they can get away with it. Ignoring harassment only confirms this.

\section{The Nature of This Obligation}

I have just argued that the fact that sexual harassment takes place under conditions of patriarchal oppression is not usually sufficient to relieve women of their moral obligation to resist that oppression by confronting their harassers. I've also argued that men, too, have an obligation to confront harassers. But what, exactly, is the nature of these obligations? To whom are women obligated when they are obligated to confront harassers? To whom are men obligated?

Recall that I argued above that the distinctive moral harm of sexual harassment is that it undermines women's autonomy. It does this by contributing to, reinforcing, and legitimating the sexist attitudes that underlie patriarchal oppression. It's important to recognize that perhaps the most pernicious harm of patriarchy is that it restricts the autonomy of the women it oppresses. If autonomy is a necessary condition for the possibility of moral obligation, then it seems reasonable to think there is a fundamental moral obligation to protect one's own autonomy. It is a woman's autonomy that makes her capable of being subject to obligations in the first place. Since the possibility of being subject to moral obligations is at least partially constitutive of moral agency, a woman's autonomy is necessary for her to be a moral agent. So her obligation to resist patriarchy is an obligation to resist that which undermines her capacity for obligation, in essence, to resist that which undermines her moral agency.

Seen in this way, women's obligation to confront the men who sexually harass them is not just a general obligation to confront some random moral harm. It is primarily a moral obligation to confront and resist behavior that undermines one's ability to be morally obligated at all. It is a special case of an obligation to preserve and protect one's moral agency. This means that a woman's obligation to confront the men who sexually harass her is primarily an obligation she has to herself..$^{11}$

But remember, the harm of sexual harassment is distinctive in how it affects its victims. Because sexual harassment both draws on and reinforces the oppressive social norms of patriarchy, when a particular woman is sexually harassed, all women are, in fact, harmed. This means that the obligation a woman has to confront a harasser is not merely an obligation she has to herself; it is also an obligation she has to all women, who suffer as a group under patriarchy.

Notice that it follows from this analysis that the obligation women have to confront sexual harassers is very different from the obligation men have. Men 
are not the victims of patriarchy, so any obligation they have to resist patriarchy cannot be an obligation they have to themselves. Rather, men's obligations to confront those men who sexually harass women is an obligation they have to women, as a group, to end the injustice of patriarchal oppression.

So the distribution of obligations looks something like this. Women have an obligation to themselves, to protect their autonomy. The also have an obligation to all other women, as a group. Men share this obligation to women as a group.

I have argued that the fact that women are oppressed is not usually sufficient to relieve them of their moral obligation to resist that oppression by confronting the men who sexually harass them. Normative considerations of fairness don't seem to remove this obligation, even if we are willing to recognize that it isn't fair that women are burdened by extra moral obligations as a result of their oppression. We can recognize that women's oppression leaves them with an unfair share of obligations and still be justified in saying that they have further obligations to resist their oppression. The fact that patriarchy harms women by burdening them with unfair obligations is just one more reason it must be eradicated.

\section{Notes}

For helpful comments on earlier drafts, I would like to thank members of The Ohio State University's Department of Philosophy and attendees of the Society for Analytic Feminism's spring 2004 conference, who attended different presentations of this essay. In particular, I would like to thank Louise Antony, Samantha Brennan, Dan Farrell, Anita Superson, and, as always, Scott Edgar.

1. Marilyn Frye's definition of oppression, particularly in its emphasis on the double binds an oppressed person experiences, where one's "options are reduced to a very few and all of them expose one to penalty, censure or deprivation" $(1983,2)$, makes clear how oppression restricts the autonomy of those who are oppressed.

2. This summary of various feminist objections to traditional conceptions of autonomy is based, in large part, on summaries given by Herta Nagl-Docekal (1998, 59-60), Alison Jaggar (2000, 452-68), and John Christman (1995, 17-39).

3. For a defense of this claim that is more thorough than the one I have sketched here, see, for example, John Christman (1995) and Diana Tietjens Meyers (1989).

4. The idea of partial autonomy follows from Faden's and Beauchamp's distinction between full and substantial autonomy (1986). They define autonomous actions as those that are performed intentionally, with understanding of relevant consequences, and in the absence of inappropriate controlling influences, but they believe that autonomy is a concept that admits of degrees. They also believe that agents require only substantial autonomy in order to be said to be autonomous in a morally relevant sense.

5. Susan Wendell has argued for a similar point (1990). 
6. For example, Marilyn Frye asks, "Can we hold ourselves, and is it proper to hold each other, responsible for resistance? Or is it necessarily both stupid cruelty and a case of 'blaming the victim' to add yet one more pressure in our lives, in each others' lives, by expecting, demanding, requiring, encouraging, inviting acts and patterns of resistance and reconstruction which are not spontaneously forthcoming?" (1985, 215-16).

7. For a useful analysis of this concern, which has become known as the problem of adaptive preferences, see, for example, Martha Nussbaum (2000, 111-61).

8. Uma Narayan (2002) might disagree with this claim. Narayan criticizes the tendency of some Western feminists to portray the agency of Third World women as if it were completely "pulverized" by patriarchy; she thinks this effaces the value and significance of the choices these women make "from the point of view of the women who make them" (2002, 422). These women are neither "dupes" nor "prisoners" of patriarchy, Narayan argues. While she admits that choices made by many Third World women are undeniably distorted by oppression, she argues that there is still active agency involved in their compliance with oppressive social structures. She advocates thinking of these women as "bargaining with patriarchy," and counsels Western feminists to be aware not just of how an oppressive practice imposes constraints on women's choices, but also how women are capable of making choices within these constraints.

Narayan might object to my claim that many Third World women lack substantial autonomy because of the patriarchal social conditions under which they live. But the point of her argument is to make a case against the legitimacy of the use of stateimposed coercion to eradicate "patriarchal practices" such as veiling; she does not discuss the issue of moral responsibility. And while she and I might disagree about exactly how much autonomy one needs in order to be considered substantially autonomous, it's not at all clear to me that she would disagree that the choices open to at least some Third World women are so restricted that they are not substantially autonomous and are thus not morally responsible.

9. It might be objected that the primary obligation here is to prevent the harm to the cat, not to confront the children. I take the case to be set up in such a way that rescuing the cat is not possible without confronting the children; surely this would amount to a case where one has a clear moral obligation to confront wrongdoers.

10. A good general strategy for confronting sexual harassers, particularly in cases like Native Companion's, is to force the harasser to see you as a person worthy of being treated with respect. Perhaps the most effective way to do this is to remind them of other women they already respect (or would, at the very least, probably purport to respect). Ask them, "Would you say that to your mother? Your sister? What about your daughter? No? Then what makes you think you can say it to me?"

11. It would be fruitful, I think, to consider this obligation to be akin to a Kantian duty of self-respect. Unfortunately, an examination of this, and a fuller defense of my claim that people have an obligation to protect their own autonomy, are both beyond the scope of this paper. 


\section{REFERENCES}

Christman, John. 1995. Feminism and autonomy. In Nagging questions: Feminist ethics in everyday life, ed. Dana Bushnell. Lanham, Md.: Rowman and Littlefield Publishers.

Faden, Ruth, and Tom Beauchamp. 1986. A history and theory of informed consent. New York: Oxford University Press.

Frye, Marilyn. 1983. The politics of reality. Trumansburg, N.Y.: Crossing Press.

1985. History and responsibility. Women's Studies International Forum, special issue, featuring Hypatia 8 (3): 215-16.

Gilligan, Carol. 1982. In a different voice: Psychological theory and women's development. Cambridge, Mass.: Harvard University Press.

Jaggar, Alison. 2000. Ethics naturalized: Feminism's contribution to moral epistemology. Metaphilosophy 31 (5): 452-68.

LeMoncheck, Linda. 1994. What's wrong with being a sex object? In Living with contradictions: controversies in feminist social ethics, ed. Alison Jaggar. Boulder, Colo.: Westview Press.

Meyers, Diana Tietjens. 1989. Self, society, and personal choice. New York: Columbia University Press.

Nagl-Docekal, Herta. 1998. Modern and political philosophy. In A companion to feminist philosophy, ed. Alison Jaggar and Iris Young. Malden, Mass.: Blackwell Publishers.

Narayan, Uma. 2002. Minds of their own: Choices, autonomy, cultural practices, and other women. In A mind of one's own: Feminist essays on reason and objectivity, $2^{\text {nd }}$ edition, ed. Louise Antony and Charlotte Witt. Boulder, Colo.: Westview Press.

Noddings, Nel. 1984. Caring: A feminine approach to ethics and moral education. Berkeley and Los Angeles: University of California Press.

Nussbaum, Martha. 2000. Women and human development: The capabilities approach. Cambridge: Cambridge University Press.

Scheman, Naomi. 1983. Individualism and the objects of psychology. In Discovering reality: Feminist perspectives on epistemology, metaphysics, methodology, and philosophy of science, ed. Sandra Harding and Merrill Hintikka. Dordrecht, The Netherlands: D. Reidel.

Sherwin, Susan. 1998. A relational approach to autonomy in health care. In The politics of women's health: Exploring agency and autonomy, ed. Susan Sherwin and the Feminist Health Care Ethics Research Network. Philadelphia: Temple University Press.

Superson, Anita. 1993a. A feminist definition of sexual harassment. Journal of Social Philosophy 24 (1): 46-64.

- 1993b. Right-wing women: Causes, choices, and blaming the victim. Journal of Social Philosophy 24 (3): 40-61.

Wallace, David Foster. 1997. Getting away from already pretty much being away from it all. In A supposedly fun thing I'll never do again. Boston: Little, Brown.

Wendell, Susan. 1990. Oppression and victimization: Choice and responsibility. Hypatia 5 (3): $15-46$. 
Copyright of Hypatia is the property of Indiana University Press. The copyright in an individual article may be maintained by the author in certain cases. Content may not be copied or emailed to multiple sites or posted to a listserv without the copyright holder's express written permission. However, users may print, download, or email articles for individual use. 